\title{
METHODOLOGY OF SOCIAL AND PEDAGOGICAL COUNSELING IN THE CONTEXT OF LIFELONG EDUCATION
}

\author{
Sergei Y. Lavrentiev ${ }^{1 *}$, Dmitry A. Krylov ${ }^{2}$, Elena V. Kondratenko ${ }^{3}$ \\ ${ }^{1}$ Assoc. Prof., Faculty of General and Vocational Education, Mari State University, Russia, \\ lavrsu@mail.ru \\ ${ }^{2}$ Assoc. Prof., Faculty of General and Vocational Education, Mari State University, Russia, \\ krilda@mail.ru \\ ${ }^{3}$ Prof, Director of Pedagogical Institute, Mari State University, Russia, \\ elena kondratenko12@mail.ru \\ *Corresponding Author
}

\begin{abstract}
Deepening socio-economic development, competition in the labor market, capital, financial resources to the fore put forward the requirements of employers to improve the personnel professionalism, the quality of professional training of graduates of educational institutions. The need for constant advanced training and professional specialists training is becoming quite justified. The concept of "education for life", which has traditionally developed over many decades, has been replaced by the concept of acquiring new knowledge, developing skills, and mastering professional skills throughout life. The negative impact of scientifically unreliable information flow on student youth, characteristic of the post-industrial era, initiates the need for the formation of competencies in selection, analysis, practical use of verified information, generation of innovative ideas to find competent solutions to emerging problems.
\end{abstract}

Keywords: methodology, pedagogical counseling, lifelong education.

\section{INTRODUCTION}

Lifelong learning contributes to meeting the need for mastering innovative technologies, increasing one's own personal and professional competitiveness in the labor market, therefore, getting closer to solving the contradiction between the requirements of employers, and insufficiently high social mobility, motivational striving for permanent training. A qualitatively high level of professional training is achieved only on condition of continuous education. This means that the concept of "education throughout life" in its essence transforms ideas about the forms, methods, means of training, the development of professional standards focused on the needs of the regional labor market, corresponding to the personal needs of consumers and buyers of educational services (Lavrentiev, Krylov, 2019).

In this regard, the theoretical and methodological generalization and analysis of world experience, both in the field of obtaining basic general education and using variable forms, methods, means in terms of developing personal and professional skills, serves as a weighty argument in favor of contemporary person continuous education importance.

The dialectics of the interpenetration of the educational sphere with other subsystems directly or indirectly affect the retrospective of the emergence and further evolutionary process of lifelong education management.

Identifying the prerequisites for the lifelong education development is appropriate in the context of the 
ongoing processes of the European educational space modernization, which has a long historical and pedagogical heritage. Lifelong education phenomenon emergence has more than eight centuries and is usually attributed to the ancient Greek philosophical teachings. Deep knowledge of the surrounding reality by great philosophers of Antiquity works - the creators of the first schools: Aristotle, Hippocrates, Plato, Solomon was reflected. In the twentieth century, of scientific and methodological support for lifelong education development was carried out by prominent scientists - researchers, cultural workers, art workers, government officials and educators: H. Hummel, F. Coombs, G. Kopazh. P. Lengrand, E. Faure et al.

\section{DISCUSSION}

For the first time the concept of "LLL" (lifelong learning) - lifelong learning by researcher P. Lengrand at the 1968 UNESCO conference was proposed. Then, the researcher's ideas in the report of the commission led by E. Faure were supported. The report, entitled "Learning to Live", continued the most significant moments of continuing education (Faure, 1972).

In the future, the concept of life-long education was approved by the participants of the Swiss (Geneva) international conference on education held in 1975. The middle of the 70s was held under the auspices of the socio-cultural integration of European countries, and the concept of lifelong education was the dominant trend of organizational, practical importance and became a global trend for several decades.

Over the past half century, innovative advances in science and technology have had a significant impact on the role and importance of lifelong education in modern society. In modern conditions, the process of appropriating knowledge and skills is no longer considered from the point of view of place and time (educational organization), the practical use of formed skills (a specific workplace). The educational process is based on the events of the student's interactive interaction with other people and the external environment that are permanently occurring in space and time. Lifelong learning can take the form of formal, informal or self-directed learning (Fischer, 2000).

The focus of the countries that signed the Bologna Declaration is the quality of lifelong education, which is ensured through the expansion of available ways of professional academic mobility, the consolidation of labor skills during practical training. Ensuring the effective implementation of the main provisions of the declaration signed by the ministers of education of European states in Bologna on June 19, 1999 should be supported not only by government agencies, but by entrepreneurs, employers of organizations of various forms of ownership, and local professional communities.

United Kingdom was one of the first countries to join the integration of educational programs. Structural and content elements of professional standards are developed directly by university teachers, employers, and governing bodies of educational organizations. Further development of academic flexibility, personal mobility, professional competitiveness of the educational space was noted by the ministers of education in a press release on the path to European education in a world "without borders" at the London summit of ministers of education in 2007.

The need to use the advantages of flexible training, which can solve the problem of the so-called "half-life of competence», is also noted by employers, who for a long time, together with universities in accordance with the increasing volume of scientific knowledge, ensure the effectiveness of managing the process of training specialists. In the course of a survey among English employers in the United Kingdom, they focus on communication skills $-86 \%$, teamwork skills $-85 \%$, self-confidence $-80 \%$, organizational skills were noted by $74 \%$ of respondents, competent oral and written speech $-71 \%$, ability to analysis and making informed decisions $-67 \%$ of the respondents. Along with the development of professional, hard skills, more and more preferences are given to soft skills, personally significant qualities in the implementation of important projects (Archer, Davison, 2008).

In the new conditions of information and technical competition, state interest in increasing human capital, the need to move from the practice of mass education to the modernization of the lifelong education system has increased in terms of students' interest in the volume and quality of the formation of personal and professional competencies (Lavrentiev, Krylov, 2018).

Modern research indicates a wide variety of ways to reveal the essential characteristics of lifelong education. The terminological diversity of the understanding of lifelong education has evolved over several decades under the influence of various socio-economic goals and tasks solved at different stages of society's development. The first factor relates to the historically established scientific and methodological discourse of adult learning throughout life. The second factor determines evolutionary changes in conceptual approaches to lifelong learning. The third interdisciplinary diversity reflects its versatility - continuing education, recurrent 
education, further education. The fourth factor is associated with a multitude of ideologically competing currents of humanistic pedagogy, socially oriented existentialism, economic determinism and other approaches that consider the purpose of lifelong education in different ways (Volles, 2014).

The organizations of the normative documents analysis regulating international relations in terms of the development of education, science, cultural cooperation under the auspices of the United Nations (UNESCO), the Organization for Economic Cooperation and Development (OECD), the European Union (EU), a change in the methodology of understanding the essence and significance of lifelong education is traced. The need for adult education has gradually evolved into a "renewable" education for those students who decide to return to an educational institution for certification. The acceleration of scientific and technological progress has initiated the need for permanent education, with a gradual transition to the concept of lifelong learning. The focus of attention gradually shifted from education within educational organizations to learning the personality, which independently forms the trajectory of its own development.

The study of the features of world practice, directions, variety of forms, methods of development of lifelong education in the developed countries of Europe and North America is of particular interest for our research. Of paramount importance in countries oriented towards industrial, innovative development of the economy in the United Kingdom, the United States, Germany, France, Italy, special emphasis is placed on the development of students' business qualities. Advanced training for the most successful adaptation to the external social environment is cultivated among the students of courses in Denmark, Belgium, Canada, Norway, Finland, Sweden, etc.

Professional training, advanced training of future specialists is carried out, as a rule, using various forms of both alternating and proper continuous training. The theoretical preparation of alternating training is carried out in specially organized centers, and the acquisition of practical skills directly in specialized organizations. The most widespread alternating education is found in Germany, the Italy, the France, Norway, Finland etc. In France, alternating training is in demand among both professional workers and those wishing to improve their skills in related fields. The duration of the alternating training is several months on the job and is organized with the direct participation of state education authorities.

The implementation of continuing education programs in the United Kingdom of Great Britain and Northern Ireland is directly embedded in the educational environment of higher education institutions. The leading positions in quality education in professional programs are held by the highly reputable universities of Oxford, Cambridge, University College London, Imperial College London and a number of others. Up to $75 \%$ of economically active UK citizens attend adult education courses.

Continuous education at the university, college is carried out using classroom, extracurricular learning. Recently, distance learning tools have been actively used in long-term or short-term courses. University centers of continuing education allow course students to use the library fund, interactively discuss the topics of upcoming seminars, round tables, conferences, share experiences, innovative pedagogical technologies. The British government publishes annual guidelines for the organization and consulting support of lifelong learning courses.

The Ministry of Education, the Ministry of Labor and Pensions, together with the Department of Employment of the Population, and commercial banks are developing special programs of economic support for graduates. A student entering a university opens a special bank account called "youth and student account" through which crediting is carried out. Lloyds Commercial Bank provides graduates with a graduate loan that allows them to use borrowed funds to find work and move to a new location. Another banking product intended for advanced training, professional retraining is "further education loan".

In the countries of Scandinavia, Russia, conducting classes in "circles» has been implemented for a long time and has become a common practice. Circles as one of the democratic forms of conducting classes in groups, together with the teacher, the students decide on the trajectory of mastering the discipline being studied.

Often offered lifelong learning programs go beyond the traditional, high-cost, commercial forms of education. For example, at the University of Delaware, the Osher Lifelong Learning Institute, more than 4,000 people are involved in consulting volunteer activities, who are united in academic volunteer cooperatives. The Department of Professional and Continuing Studies conducts training in Master's programs in economics and entrepreneurship for teachers, leadership for educators, a master in modern educational technologies, etc.

For adult learners, school teachers, tutors, social workers, at most universities and colleges in the United 
States a variety of certified courses are organized. Eastern Connecticut State University practices students' earning academic credits in the process of volunteer, community-based consulting support for low-income groups of people, people in difficult life situations.

Canada's lifelong learning system allows course participants in pre-approved educational institutions to use a portion of their own retirement savings plan

The introduction of lifelong education in the educational system of France testifies to its rather long path of transformation. Rapid changes in the French education system were not possible due to the teacher's lack of public officer status. However, in the 21st century, the educational reforms of the French government led to the development of qualitatively new professional standards, financial assistance to popular teacher development programs was strengthened, and vocational training institutions were formed.

German continuing education is carried out in specially created modernization centers. Teachers in Germany have public officer status and the law establishes a standard for their mandatory regular training. In Denmark, school teachers are state employee and the lifelong learning model provides for their ongoing training. Danish teachers have a choice of continuing education programs, and curriculum strategies are developed based on their region's needs.

\section{CONCLUSION}

Thus, the development of continuing education programs corresponds to the long-term development strategy of the state, thereby responding to the vector of constant development of various professional groups of society. Continuing education is formed as a single system of integrative organic interaction of all components, in space and time, and should be capable of flexible adaptation in relation to global threats to the socio-economic impacts of the external environment.

\section{REFERENCE LIST}

Lavrentiev S.Y., Krylov D.A. Features of innovative development of educational consulting abroad // Bulletin of the Mari State University. 2019.Vol. 13.No. 3.P. 358-364. DOI: 10.30914 / 2072-6783-2019-13-3358-364.

Faure, E. Learning to Be: the World of Education today and tomorrow. Paris: UNESCO, 1972. https://unesdoc.unesco.org/ark:/48223/pf0000001801.

Fischer, Gerhard (2000). "Lifelong Learning - More than Training" in Journal of Interactive Learning Research, Volume 11 issue 3/4 pp 265-294. http:///3d.cs.colorado.edu/ gerhard/papers/ll199.pdf.

London Communiqué. Towards the European Higher Education Area: responding to challenges in a globalized world. 18 May 2007. - URL: http://www.ehea.info/Uploads.

Archer W. \& Davison J. (2008). Graduate employability: what do employers think and want? London: The Council for Industry and Higher Education (CIHE). - URL: http://aces.shu. ac.uk/support/staff/employability/resources.

Lavrentiev S.Y., Krylov D.A. Consulting innovative processes in the university: features and characteristics // Modern problems of science and education. - 2018. - No. 6. URL: http://www.scienceeducation.ru/ru/article/view?id=28426.

Archer W. \& Davison J. (2008). Graduate employability: what do employers think and want? London: The Council for Industry and Higher Education (CIHE). - URL:http://aces.shu. ac.uk/support/staff/employability/resources.

Volles, N. (2014). Lifelong learning in the EU: changing conceptualisations, actors, and policies. Studies in Higher Education, 1-21. http://www.tandfonline.com/doi/abs/10.1080/03075079.2014.927852.

Professional and continuing studies. University of Delaware hosts Osher Lifelong Learning Institute http://www.pcs.udel.edu/osher-lifelong-learning.

Credit for Lifelong Learning (CLL). Eastern Connecticut University. URL: https://www.easternct.edu/continuing-studies/cll.html.

Agency, Canada Revenue. "Lifelong Learning Plan (LLP) - Canada.ca". www.cra-arc.gc.ca. 